\title{
Meningkatkan Efisiensi Skema Irigasi Cascade di Daerah Irigasi Tampo, Sumatera Barat
}

\author{
Improving Efficiency of Cascade Irrigation Scheme in Tampo \\ Irrigation District, West Sumatra
}

\author{
Elvi Roza Syofyan \& Revalin Herdianto
}

Jurusan Teknik Sipil Politeknik Negeri Padang Kampus Limau Manis Padang

Telp.0751-72590 Fax.0751-72576 Email: syofyan_er@yahoo.co.id, revalin.herdianto@gmail.com

\begin{abstract}
Current water use practice in Tampo Irrigation District is thought as inefficient, since water from main canal is drained to neighboring stream without further use by downstream farms. The remaining paddy farm receives less water from the same source canal. As the result the farms could only harvest once per year. A new irrigation scheme is proposed by diverting water back to the main canal to be used by farms downstream the canal. The proposed method is by using DEM and GIS information, coupled with computation of current water use of the existing farms.

The study is begun by identifying the existing farms in topography, irrigation networks, and water use. We use $30 \mathrm{~m}$ DEM by ASTER GDEM, coupled with Google Earth to identify stream networks and to delineate basin. The results are confirmed with field measurement in which elevation of structures such as weir, gates, hubs are recorded using GPS. Pertinent points in the field are also recorded by GPS. The existing farms are delineated and marked. Water flow rate are measured in the field using traditional method.

We found that the existing water use is insufficient to irrigate the irrigation district. Instead of improving efficiency of the irrigation scheme, water needs additional supply by various means.

Otherwise crops cannot be increased more than once a year. We identified another potential water source near the irrigation network that can be directly connected to the existing network. This could irrigate another 100 hectares land.
\end{abstract}

Keywords: Irrigation, DEM, GIS, Network

\section{PENDAHULUAN}

Daerah Irigasi Tampo (D.I. Tampo) di Kabupaten Tanah Datar merupakan sistem irigasi yang unik, karena air dari daratan atas pada akhirnya akan mengalir kembali ke sungai utamanya (Sungai Tampo) setelah digunakan untuk irigasi. Saat ini total area pelayanan Tampo D.I. sekitar 1.437 hektar, terdiri dari 65 sistem irigasi di lima wilayah (nagari). Air untuk tanaman pangan terutama dipasok oleh Sungai Tampo yang mengalir dari daratan atas sepanjang tangkapan sekitar $25 \mathrm{~km}$ panjang Penggunaan air total kira-kira 2.500 liter / detik selama musim puncak, dan naik menjadi sekitar 1.200 liter / detik selama musim tanam normal. Di daerah tangkapan bagian atas, air dapat memasok tanaman 2 kali per tahun. Di daerah tangkapan air di bagian hilir, tanaman dapat dilakukan 5 kali dalam dua tahun. D.I. Tampo saat ini mengalami kekurangan air akibat fluktuasi ketersediaan air. Perubahan iklim menyebabkan musim kemarau lebih lama dan intensitas curah hujan yang lebih tinggi pada musim hujan yang tidak sesuai dengan kebutuhan air. Oleh karena itu, ada kekhawatiran yang berkembang dalam keberlanjutan masa depan produksi tanaman pangan di wilayah ini.

Bagian atas DAS Tampo terletak pada ketinggian $2.774 \mathrm{~m}$, dengan daerah tangkapan air sekitar $60 \mathrm{~km} 2$. Sungai ini merupakan anak sungai Indragiri Basin, mengalir dari Utara ke Selatan. Anak sungai tersebut bergabung dengan Sungai Sinamar sebelum akhirnya masuk ke Sungai Indragiri di timur. Sungai Tampo adalah sungai khas di Sumatera Barat: curam, pendek, dan berfluktuasi secara musiman. Di musim hujan, debit sungai sering membanjiri daerah sekitarnya di tengah dan hilir sungai. Aliran sungai sering membawa puing dan sedimen 
dan airnya sangat keruh. Pada musim kemarau, aliran dasar sangat jelas dengan debit yang jauh lebih sedikit dibanding musim hujan. Ini adalah paradoks untuk kebutuhan air untuk irigasi dimana kebutuhan air tinggi di musim kemarau dan rendah atau tidak ada di Indonesia Musim hujan, karena kebutuhan air untuk tanaman dipasok secara memadai melalui presipitasi.

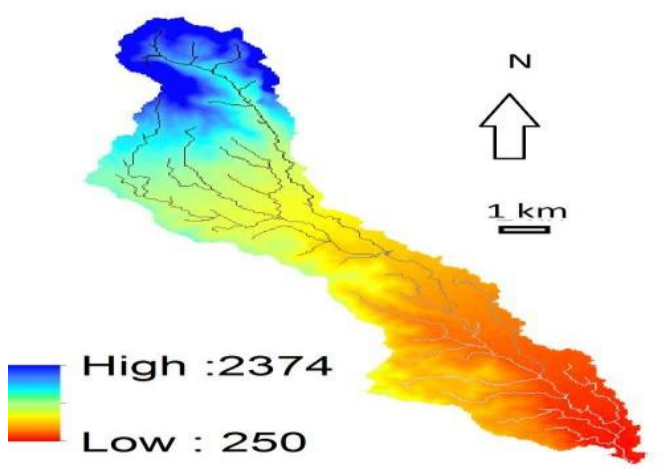

Gambar 1. Sungai Batang Tampo dan anak sungainya.

Irigasi permukaan secara gravitasi merupakan salah satu tipe irigasi yang paling luas digunakan karena kesederhanaan sistemnya dan biaya operasional yang relatif rendah (USGS, 2014; FAO 2, 2014). Kelemahan dari sistem gravitasi ini adalah ketergantungan yang sangat tinggi terhadap topografi areal yang diairi, baik dari skema pemberian (supply) maupun skema pembuangan (drain). Untuk daerah yang curam dimana elevasi sawah relatif lebih tinggi daripada sumber air, misalnya sungai, maka mengalirkan air ke sawah membutuhkan upaya lebih seperti dengan membangun bendung, sedangkan kelebihan air bisa dikembalikan ke sungai dengan mudah dari sawah yang berada di sebelah hilir. Sebaliknya di daerah yang landai dan elevasi sungai relatif lebih tinggi daripada sawah, maka membuang lapisan pengganti air bisa merupakan suatu masalah, sedangkan mensuplai kebutuhan air bisa dilakukan dengan lebih mudah karena tidak membutuhkan bangunan peninggi muka air yang terlalu mahal.

Karena topografi alamnya, sebagian area persawahan di Sumatera Barat berada di daerah yang berbukit-bukit yaitu di Kabupaten Solok, Tanah Datar, Agam, Limapuluh Kota, dan Sijunjung. Sumber air utama berasal dari hujan dan sungai. Walaupun Sumatera Barat memiliki banyak sungai, pemanfaatan air sungai belum optimal karena air sungai sulit untuk menjangkau persawahan di sebelah hulu karena perbedaan elevasi yang besar. Hal ini menyebabkan tingkat produktivitas sawah di area yang rendah biasaanya lebih tinggi daripada sawah yang berada di daerah yang lebih tinggi karena daerah ini mendapatkan keuntungan dari suplai air dari hulu. Sedangkan di daerah hulu, produktivitasnya sangat tergantung dari musim hujan.

Suatu sistem irigasi disebut seri apabila sawah yang berada di hilir memperoleh air dari petak yang berada di hulu, dan disebut paralel jika beberapa petak memperoleh air dari sumber yang sama, misalnya sungai (Playan dan Mateos, 2006). Contoh sistim seri adalah sistim irigasi bertingkat (cascade) atau sistim berantai (chain). Dengan sistim ini, sawah yang berada pada daerah paling hulu mengambil sebagian air dari hulu sungai pada saat debit mencukupi. Pengambilan bisa dengan bendung tetap, maupun bangunan non permanen seperti batu susun. Air dibawa ke petak sawah melalui saluran dan diatur dengan bangunan bagi- sadap. Air dari petak teratas dialirkan lagi ke petak yang berada di bawahnya, demikian seterusnya sampai mencapai sawah paling ujung. Dari sini air dialirkan kembali ke sungai untuk menambah debit sungai supaya dapat digunakan kembali untuk sawah yang berada di daerah lebih hilir. Dengan mekanisme ini, kehilangan air dapat ditekan karena sebagian air yang diambil kembali lagi ke sungai untuk mengairi daerah irigasi di hilirnya. Sistim irigasi bertingkat seperti ini diterapkan di daerah irigasi yang berada di sepanjang Batang Tampo, Kabupaten Tanah Datar. Dengan debit musim kemarau yang sangat kecil, sekitar 300 liter/detik, Batang Tampo menjadi sumber air bagi 65 sistim irigasi disekitarnya, dengan luas total 1.437 ha (BWS V, 2009). Karena topografi daerah aliran sungai (DAS) yang curam di bagian hulu, sebagian debit yang diambil untuk irigasi dapat dikembalikan lagi ke hilir 
sungai, sehingga daerah hilir memiliki produktivitas yang cukup tinggi dengan siklus 5 kali panen dalam 2 tahun.

Meskipun demikian, terdapat beberapa persoalan mendasar dalam penataan jaringan irigasi dan pemakaian air di sepanjang Batang Tampo. Persoalan pertama adalah ketimpangan produktivitas daerah hulu dan hilir berkaitan dengan musim. Daerah irigasi di sebelah hilir mampu panen 5 kali dalam 2 tahun, dengan satu musim diantaranya memanfaatkan curah hujan. Tetapi di bagian hulu, produktivitas lahan lebih rendah yaitu 2 kali panen setahun, karena siklus tanam tergantung pada hujan disamping air sungai (Pusat Studi Irigasi Unand, 1987). Tingginya fluktuasi debit antara musim hujan dan musim kemarau mengakibatkan turunnya produktivitas di musim kemarau. Situasi ini menyebabkan petani tidak dapat menentukan waktu tanam, dan hasil panen belum tentu sesuai dengan yang diharapkan.

Persoalan kedua terkait dengan ketidakefisienan pemakaian air yaitu dalam tata letak saluran dan petak tersier. Salah satu daerah irigasi di bagian paling hulu, yaitu Bandar Gadang, mengambil air dengan jumlah yang cukup besar untuk lahan seluas 107.50 ha (BWS V, 2009). Namun air ini tidak dikembalikan ke Batang Tampo, melainkan mengalir ke Batang Sinamar di sebelah timur dengan elevasi yang lebih rendah daripada batang Tampo. Hal ini mengurangi peluang pemanfaatan daerah irigasi di sebelah hilir karena air yang masuk ke Batang Sinamar tidak bisa masuk lagi ke Batang Tampo. Selain itu, pengambilan air yang tidak didukung suatu perhitungan yang cermat mengakibatkan air tidak termanfaatkan secara maksimum

Selama ini upaya untuk mengatasi kedua masalah tersebut selalu dikaitkan dengan upaya-upaya menambah debit, misalnya dengan mencari sumber air baru atau dengan membangun jaringan suplesi dari sungai terdekat. Belum ada upaya untuk meningkatkan efisiensi pemakaian air baik di hulu maupun di daerah hilir. Disamping itu karena sistim irigasi ini dikelola dengan cara tradisional, pengambilan air semata-mata didasarkan atas kebisaaan. Sistim pembagian ini menjadi kritis ketika persediaan di sungai makin berkurang sedangkan kebutuhan di petak sawah tetap tinggi. Kondisi ini potensial memicu konflik antar petani pemakai air, sehingga perlu dicari jalan keluar dengan pendekatan modern dan sosial, lebih dari sekedar mencari sumber air baru atau memperbaiki dan menambah bangunan irigasi.

Salah satu faktor yang mempengaruhi efisiensi irigasi adalah topografi (Bos, 1990; Ali, 2010; FAO 1, 2014), karena topografi berperan dalam menentukan energi yang diperlukan untuk mengalirkan dan mendistribusikan air dari sumbernya ke petak sawah. Karena itu dalam perencanaan petak dan jaringan irigasi, topografi adalah informasi utama yang harus diperhitungkan dengan benar. Informasi topografi ini diolah dengan bantuan teknologi seperti Global Positioning System (GPS), remote sensing, dan Global Information System (GIS).

Teknologi modern yang telah digunakan untuk mengevaluasi kinerja suatu sistem irigasi adalah dengan penginderaan jarak jauh (remote sensing) yaitu menggunakan informasi yang diberikan oleh satelit seperti Digital Elevation Model (DEM) untuk data topografi, citra (image), surface thermal (temperatur permukaan), indeks tanaman (vegetation index), dan curah hujan (Herdianto dkk., 2010). Jenis satelit yang digunakan untuk penelitianpenelitian sebelumnya antara lain NOAA (National Oceanography and Atmospheric Administration) untuk menilai kinerja irigasi di Srilanka (Bandara, 2003) dan di Iran (Akbari dkk., 2007; Toomanian dkk., 2004). Satelit IKONOS, RADARSAT, dan ASTER digunakan untuk pertanian di India (Hakeem dan Raju, 2009; Saindranath dkk., 2000; Sarwar dan Bill, 2007). Data satelit lain seperti vegetation index digunakan untuk monitoring irigasi di Nebraska, Amerika Serikat (Dappen, 2003) dan di India (Murthy dkk., 1998) dan memprediksi perilaku tanaman (Herdianto dkk., 2013). Selain itu data satelit juga digunakan untuk estimasi evapotranspirasi tanaman (Granger 
1989, 1995, 2000; Mauser dan Schadlich 1998; Bastiaanssen dan Bos 1999, Bastiaanssen dkk. 1999; Bastiaanssen 2000; Reynolds $d k k$. 2000). Penggunaan data satelit ini bisaanya digabungkan dengan Geographic Information System (GIS) untuk memaparkan informasi spasial tentang data- data yang diperoleh.

Dengan GIS, topografi dan posisi petak sawah dapat dipetakan dengan detil sehingga kehilangan energi bisa diminimalkan dalam perencanaan jaringan. Disamping itu GIS dapat mengelompokkan data yang sejenis menjadi cluster-cluster sehingga bisa diinterpretasikan sesuai dengan kepentingan terkait. GIS juga sudah digunakan untuk memvisualisasikan dan memaparkan hasil evaluasi terhadap kinerja irigasi (Sakthivadivel dkk. 1999; Liang dan Wu, 2012), dan memetakan kebutuhan air irigasi teoritis (Knox $d k k$. 1996; Knox and Weatherhead 1999; El-Magd dan Tanton, 2005). Dalam sistem irigasi bertingkat, informasi penting yang dibutuhkan adalah beda elevasi di hulu pengambilan dan di titik pembuangan akhir serta kebutuhan air untuk masing-masing petak tersier.

\section{METODOLOGI}

a. Identifikasi Kondisi Topografi

Identifikasi kondisi topografi daerah irigasi dilakukan dengan menggunakan data primer dan sekunder. Data primer dikumpulkan dengan menelusuri patok-patok penting (benchmark) di sepanjang sungai di bagian hulu dan daerah irigasi bagian hulu (Bandar Gadang) dengan menggunakan GPS dan teodolit. Elevasi titik-titik benchmark diukur dengan GPS Mapping dengan keakuratan hingga $1 \mathrm{~cm}$. Patok-patok ini dikonfirmasi dengan peta daerah irigasi yang ada di instansi terkait seperti dinas pertanian. Elevasi titik-titik benchmark ini diplot ke GIS untuk mendapatkan gambaran tentang elevasi daerah irigasi dibandingkan dengan elevasi sungai Batang Tampo. Data sekunder diperoleh dari peta topografi skala 1:20000 yang dibuat sejak jaman Belanda. Peta topografi skala 1:20000 ini dikombinasi dengan DEM (Digital Elevation Model) dari ASTER
GDEM dengan resolusi $30 \mathrm{~m}$. Analisa jaringan sungai Batang Tampo beserta anak-anak sungai dilakukan dengan open source TAS (Terrain Analysis System) dengan menggunakan DEM. Data posisi dan elevasi titik-titik benchmark ini dimasukkan ke DEM untuk analisa lanjutan. b. Inventarisasi dan Evaluasi Jaringan Existing

Tata letak daerah irigasi existing beserta jaringan dan bangunan-bangunan untuk DI Bandar Gadang diperoleh dari Dinas Pertanian Kabupaten Tanah Datar. Skema pemberian air dan pola tanam diperoleh dari Dinas Pertanian dan wawancara dengan petani dan petugas dari Dinas Pertanian. Petak sawah dan jaringan diplot kedalam DEM sehingga diperoleh layer berupa posisi dan elevasi titik-titik yang terpenting seperti titik pengambilan di sungai, sawah tertinggi, sawah terendah, dan titik pembuangan terakhir. Evaluasi dilakukan dengan menghitung elevasi yang tersedia untuk pengambilan dan pembuangan dan tinggi energi yang tersedia di sungai mengacu kepada benchmark yang sudah digambarkan.

c. Perhitungan Kebutuhan Air Menurut Pola Tanam yang ada

Kebutuhan air untuk irigasi merupakan kebutuhan komsumtif tanaman untuk evapotranspirasi (ET) yang bervariasi menurut tingkat pertumbukan tanaman. Jumlah air yang diambil dari sungai adalah selisih antara curah hujan efektif (Re) dengan ET, penggantian lapisan air (WLR) dan perkolasi (P). Data-data dasar untuk menghitung ET dan $\mathrm{P}$ diperoleh dari Dinas Pertanian. ET dihitung dengan metode Penman modifikasi. Curah hujan efektif (Re) dihitung dari curah hujan harian yang diperoleh dari stasiun klimatologi Lintau Buo. Kebutuhan air tanaman di sawah (NFR):

$$
\mathrm{NFR}=\mathrm{ETc}+\mathrm{P}+\mathrm{WLR}-\mathrm{Re}
$$

d. Perhitungan Ketersediaan air di sungai. Ketersediaan air di sungai diperlukan untuk merencanakan skema pengambilan air berdasarkan kebutuhan air irigasi. Pola ketersediaan air belum tentu sesuai dengan pola tanam dan kebutuhan tanaman. Data 
debit diperoleh dari Dinas PSDA Propinsi Sumatera Barat. Ketersediaan air selama 10 tahun di plot terhadap kebutuhan air dari pola tanam selama sepuluh tahun. Hasil analisa ini dapat memberikan gambaran tentang skema pemakaian air dan produktivitas yang dicapai selama periode tersebut. Pengukuran sesaat dilakukan di sungai untuk mencocokkan antara kecepatan, luas penampang, dan debit saat pengukuran dan dibandingkan dengan data sekunder yang diperoleh dari Dinas PSDA Propinsi Sumatera Barat. Pengukuran debit dilakukan dengan current meter digital, penampang sungai diukur dengan meteran. Kedalaman sungai diukur dengan mistar/rambu ukur.

\section{HASIL DAN PEMBAHASAN}

a. Identifikasi Kondisi Topografi Identifikasi kondisi topografi dimaksudkan untuk mengetahui elevasi jaringan dan petak sawah dalam D.I. Bandar Gadang. Identifikasi topografi dilakukan dengan survey menggunakan GPS Mapping, GPS Handheld untuk menentukan koordinat dan elevasi titik-titik penting seperti bangunan pengambilan, bendung, sawah, jaringan irigasi. Elevasi titik-titik ini diperlukan untuk menata ulang dan kemungkinan mengembalikan drainase sawah di hulu ke Batang Tampo untuk memperbesar debit di hilir. Survey topografi ini dibantu dengan Google Earth di lapangan untuk mengecek lokasi titik-titik survey.

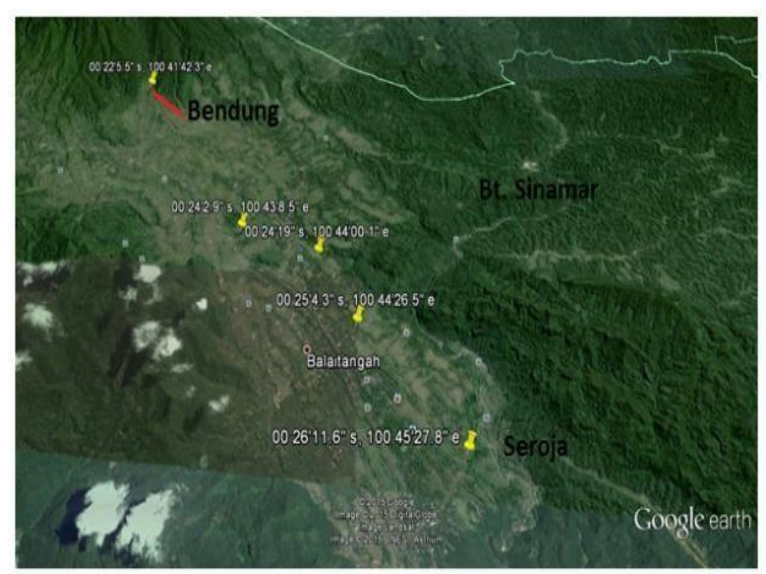

Gambar 2. Lokasi DI. Tampo

Data-data yang dikumpulkan dari survey di plot ke Google Earth. Data sekunder untuk analisa GIS diambil dari ASTER GDEM dengan resolusi $30 \mathrm{~m}$, atau lebih baik daripada SRTM $(90 \mathrm{~m})$. Pada peta GIS ini bisa dilihat ketinggian titik-titik yang disurvey secara detail. Pada Gambar 4.2. terlihat elevasi bendung dan intake serta saluran relatif terhadap Batang Sinamar yang menjadi titik pembuangan drainase dari Bandar Gadang.

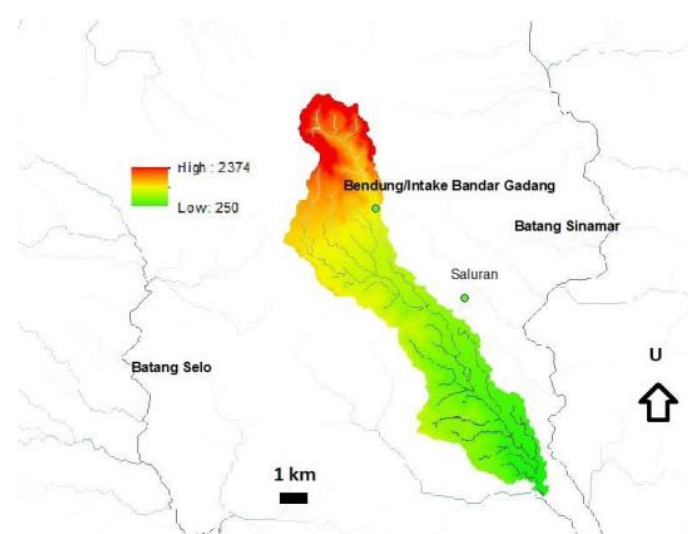

Gambar 3. Elevasi catchment area Bt. Tampo.

D.I.Tampo berada pada elevasi $250 \mathrm{~m}$ sampai $2374 \mathrm{~m}$ dpl. Elevasi pengambilan Bandar Gadang berada pada elevasi 976.25 m. Dari Gambar 4.2. terlihat bahwa elevasi D.I. Tampo berada cukup tinggi dari Batang Sinamar. Pengambilan ke arah timur sebagian besar masuk ke anak-anak sungai Bt. Sinamar. Batang Sinamar berada pada elevasi sekitar $400 \mathrm{~m}$.

b. Inventarisasi dan Evaluasi Jaringan Existing

Survey meliputi evaluasi terhadap kondisi jaringan existing di D.I. Tampo Bandar Gadang. Jaringan ini meliputi bendung/free intake, saluran, bangunan pengatur, serta pertemuan dan pembuangan akhir. Dari survey diketahui kondisi jaringan. Pembuangan akhir dari D.I. Bandar Gadang memasuki Sub DAS Sinamar.

Evaluasi jaringan irigasi yang ada dilakukan dengan sistim walk through atau menelusuri jaringan irigasi Tampo. Penelusuran ini dimulai dari hulu pengambilan, yaitu DI Bandar Gadang, sampai ke hilir. Evaluasi dilakukan terhadap jaringan yang ada, untuk kemudian dibuatkan matriks. Hasil dari penelusuran dipaparkan sebagai berikut. 


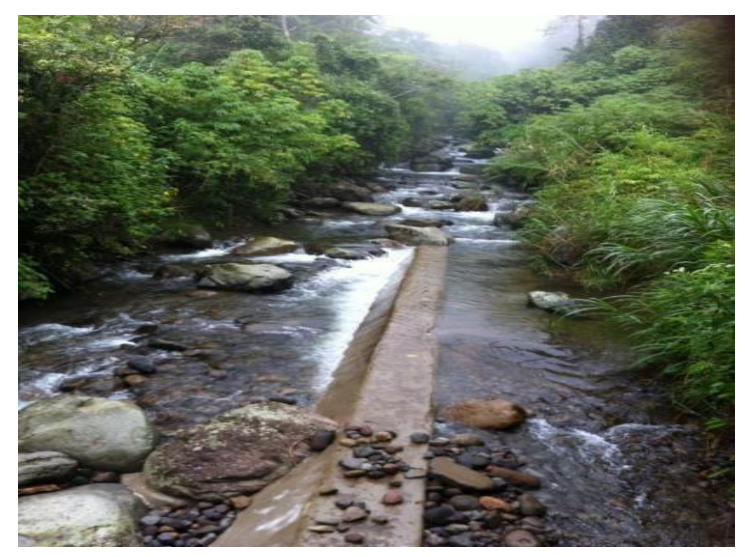

Gambar 7. Free Intake Bandar Gadang.

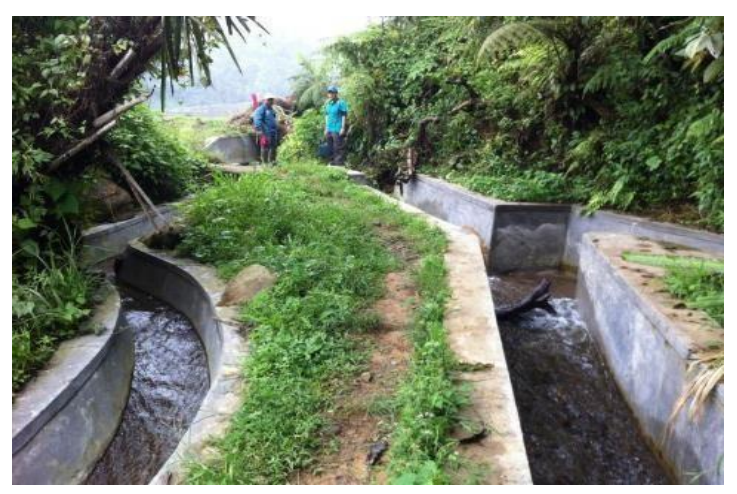

Gambar 8. Cabang Intake Bandar Gadang. Gadang.

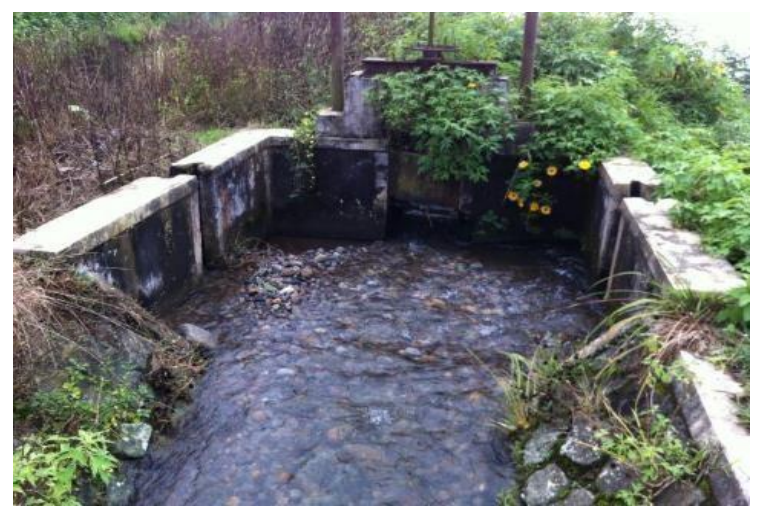

Gambar 9. Sedimentasi di pintu pengambilan
Pengambilan di Bandar Gadang tidak berfungsi sebagaimana mestinya karena penumpukan sedimen di bangunan pengambilan (Gambar 9.).

c. Perhitungan Kebutuhan Air dan $\mathrm{ET}_{\mathrm{o}}$ $\mathrm{ET}_{\mathrm{o}}$ dihitung untuk kondisi setempat dengan memperhitungkan faktor-faktor klimatologi, seperti suhu, kelembaban udara, angina, penyinaran. $\mathrm{ET}_{\mathrm{o}}$ digunakan untuk menghitung kebutuhan air untuk irigasi. Dengan menggunakan data stasiun Buo, diperoleh $\mathrm{ET}_{\mathrm{o}}$ sebagai berikut:

Tabel 1. $\mathrm{ET}_{\mathrm{o}}$ D.I. Tampo

\begin{tabular}{|c|l|c|c|c|c|c|c|c|c|c|c|c|c|}
\hline No & Bulan & Jan & Feb & Mar & Apr & Mei & Jun & Jul & Agt & Sep & Okt & Nov & Des \\
\hline 1 & $\begin{array}{l}\text { Temperatur rata- } \\
\text { rata (T) }\end{array}$ & 27,9 & 27,7 & 27,5 & 27,3 & 27,6 & 27,5 & 27,5 & 27,8 & 27,6 & 27,6 & 27,3 & 27,6 \\
\hline 2 & $\begin{array}{l}\text { Kelembaban } \\
\text { rata-rata (Rh) } \%\end{array}$ & 95,7 & 95,6 & 95,7 & 95,7 & 95,5 & 94,9 & 95,5 & 95,7 & 95,7 & 95,5 & 95,6 & 95,7 \\
\hline 3 & $\begin{array}{l}\text { Kelembaba } \\
\text { maksimum } \\
\text { (Rh maks) } \%\end{array}$ & 90,0 & 89,0 & 89,0 & 87,0 & 86,0 & 85,0 & 86,0 & 87,0 & 84,0 & 82,0 & 85,0 & 87,0 \\
\hline 4 & $\begin{array}{l}\text { Penyinaran } \\
\text { Matahari (\%) }\end{array}$ & 20,2 & 31,9 & 24,6 & 33,3 & 40,3 & 31,6 & 37,8 & $(1,0)$ & $(1,0)$ & $(1,0)$ & $(1,0)$ & $(1,0)$ \\
\hline
\end{tabular}




\begin{tabular}{|c|c|c|c|c|c|c|c|c|c|c|c|c|c|}
\hline 5 & \begin{tabular}{|l} 
Kecepatan \\
Angin (Uday) \\
Knot
\end{tabular} & 13,5 & 12,7 & 5,7 & 9,1 & 20,8 & 36,8 & 29,9 & 18,0 & 14,9 & 19,3 & 98,8 & 39,0 \\
\hline 6 & $\begin{array}{l}\text { Uday/ } \\
\text { Unight }\end{array}$ & 13,5 & 13,5 & 13,5 & 13,5 & 13,5 & 13,5 & 13,5 & 13,5 & 13,5 & 13,5 & 13,5 & 13,5 \\
\hline 7 & ea (mbar) & 34,4 & 35,0 & 35,8 & 36,6 & 36,7 & 35,3 & 34,6 & 26,9 & 36,4 & 36,4 & 37,3 & $\overline{36,0}$ \\
\hline 8 & $\mathrm{Rh} / 100$ & 1,0 & 1,0 & 1,0 & 1,0 & 1,0 & 0,9 & 1,0 & 1,0 & 1,0 & 1,0 & 1,0 & 1,0 \\
\hline 9 & ed (mbar) & 32,9 & 33,4 & 34,3 & 35,0 & 35,1 & 33,5 & 33,0 & 25,7 & 34,9 & 34,8 & 35,6 & 34,4 \\
\hline 10 & $\begin{array}{l}\text { (ea - ed) } \\
\text { mbar }\end{array}$ & 1,5 & 1,5 & 1,5 & 1,6 & 1,6 & 1,8 & 1,6 & 1,2 & 1,6 & 1,6 & 1,6 & 1,6 \\
\hline 11 & $\begin{array}{l}\mathrm{f}(\mathrm{u})=0,27 * \\
\left(1+\mathrm{U}^{*} 1.825^{*}\right. \\
\left.0.7606^{*} 24 / 100\right)\end{array}$ & 1,5 & 1,4 & 0,8 & 1,1 & 2,1 & 3,6 & 3,0 & 1,9 & 1,6 & 2,0 & 9,2 & 3,8 \\
\hline 12 & $(1-W)$ & 0,3 & 0,3 & 0,3 & 0,3 & 0,3 & 0,3 & 0,3 & 0,3 & 0,3 & 0,3 & 0,3 & 0,3 \\
\hline 13 & $\begin{array}{l}(1- \\
\mathrm{W}) *(\mathrm{f}(\mathrm{u}) *(\mathrm{ea}- \\
\mathrm{ed})\end{array}$ & 0,6 & 0,6 & 0,3 & 0,5 & 1,0 & 1,8 & 1,5 & 0,6 & 0,8 & 0,9 & 4,2 & 1,8 \\
\hline 14 & $\mathrm{Ra}$ (mm/hari) & 16,3 & 16,2 & 15,5 & 14,3 & 12,9 & 13,2 & 12,5 & 13,6 & 14,8 & 15,9 & 16,1 & 16,1 \\
\hline 15 & $\mathrm{n} / \mathrm{N}$ & 0,1 & 0,2 & 0,2 & 0,2 & 0,3 & 0,2 & 0,3 & $(0,0)$ & $(0,0)$ & $(0,0)$ & $(0,0)$ & $(0,0)$ \\
\hline 16 & $\left(0.25+0.5^{*} \mathrm{n} / \mathrm{N}\right)$ & 0,3 & 0,4 & 0,3 & 0,4 & 0,4 & 0,4 & 0,4 & 0,2 & 0,2 & 0,2 & 0,2 & 0,2 \\
\hline 17 & Rs & 5,1 & 5,7 & 5,1 & 5,2 & 5,0 & 4,7 & 4,8 & 3,4 & 3,7 & 3,9 & 4,0 & 4,0 \\
\hline 18 & $\begin{array}{l}\text { Rns }=(1-L) \\
* \text { Rs } \quad, \quad L=0.25\end{array}$ & 3,8 & 4,3 & 3,8 & 3,9 & 3,8 & 3,6 & 3,6 & 2,5 & 2,7 & 2,9 & 3,0 & 3,0 \\
\hline 19 & $f(t)$ & 16,3 & 16,2 & 16,2 & 16,2 & 16,2 & 16,2 & 16,1 & 16,3 & 16,2 & 16,2 & 16,2 & 16,2 \\
\hline 20 & $\begin{array}{l}\mathrm{f}(\mathrm{ed})=0.34- \\
\left.0.044^{*} \mathrm{ed}^{\wedge} 0.5\right)\end{array}$ & 0,1 & 0,1 & 0,1 & 0,1 & 0,1 & 0,1 & 0,1 & 0,1 & 0,1 & 0,1 & 0,1 & 0,1 \\
\hline 21 & $\begin{array}{l}\mathrm{f}(\mathrm{n} / \mathrm{N})= \\
(0.1+0.9(\mathrm{n} / \mathrm{N}))\end{array}$ & 0,2 & 0,3 & 0,2 & 0,3 & 0,3 & 0,3 & 0,3 & 0,1 & 0,1 & 0,1 & 0,1 & 0,1 \\
\hline 22 & $\begin{array}{l}\mathrm{Rnl}= \\
\mathrm{f}(\mathrm{t}) * \mathrm{f}(\mathrm{ed}) * \mathrm{f}(\mathrm{n} / \mathrm{N})\end{array}$ & 0,3 & 0,4 & 0,3 & 0,4 & 0,4 & 0,4 & 0,5 & 0,2 & 0,1 & 0,1 & 0,1 & 0,1 \\
\hline 23 & $\begin{array}{l}\mathrm{Rn}=\mathrm{Rns}- \\
\mathrm{Rnl}\end{array}$ & 3,5 & 3,9 & 3,5 & 3,5 & 3,3 & 3,1 & 3,1 & 2,3 & 2,6 & 2,8 & 2,9 & 2,9 \\
\hline 24 & W & 0,7 & 0,7 & 0,7 & 0,7 & 0,7 & 0,7 & 0,7 & 0,7 & 0,7 & 0,7 & 0,7 & 0,7 \\
\hline 25 & $\mathrm{~W}^{*} \mathrm{Rn}$ & 2,5 & 2,8 & 2,5 & 2,5 & 2,4 & 2,3 & 2,1 & 1,7 & 1,8 & 2,0 & 2,1 & 2,0 \\
\hline 26 & $\mathrm{c}$ & 1,0 & 1,0 & 1,0 & 1,0 & 1,0 & 1,0 & 1,0 & 1,0 & 1,0 & 1,0 & 1,0 & 1,0 \\
\hline 27 & $\begin{array}{l}\text { Eto } \\
=c^{*}(\mathrm{~W} * \mathrm{Rn}+ \\
(1-\mathrm{W}) * \mathrm{f}(\mathrm{U}) *(\text { ea- } \\
\text { ed })\end{array}$ & 3,2 & 3,3 & 2,8 & 2,9 & 3,2 & 3,9 & 3,5 & 2,2 & 2,5 & 2,8 & 6,0 & 3,6 \\
\hline
\end{tabular}




\section{d. Sumber air potensial}

Pada saat survey, ditemukan sebuah sumbar air potensial yang berada di Kenagarian Tanjung Bonai. Sumbar air ini selama ini sudah diketahui oleh masyarakat, namun tidak termanfaatkan karena diujung saluran, air hilang kedalam tanah. Ini disebabkan karena kondisi batuan yang porous di bawah tanah. Selama ini pemanfaatan air tersebut hanya untuk sawah yang berada di samping saluran (1.k. 2 ha). Saluran ini terdapat pada sebuah cekungan yang airnya berasal dari perbukitan di hulu. Di cekungan ini mengalir dua saluran dengan debit masing-masing 50 liter/detik. Dengan estimasi kebutuhan air rata-rata 1 liter/detik/ha, maka sumber air ini dapat mengairi lahan seluas 100 ha.

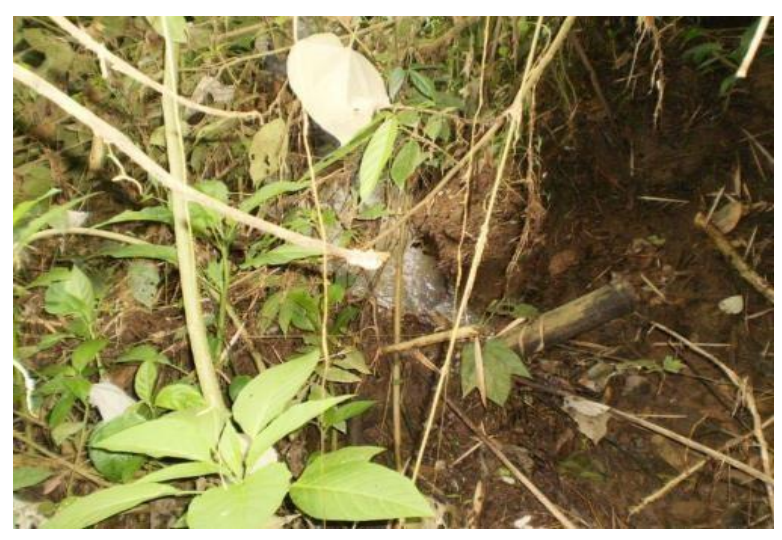

Gambar 10. Potensi air yang hilang ke dalam Tanah

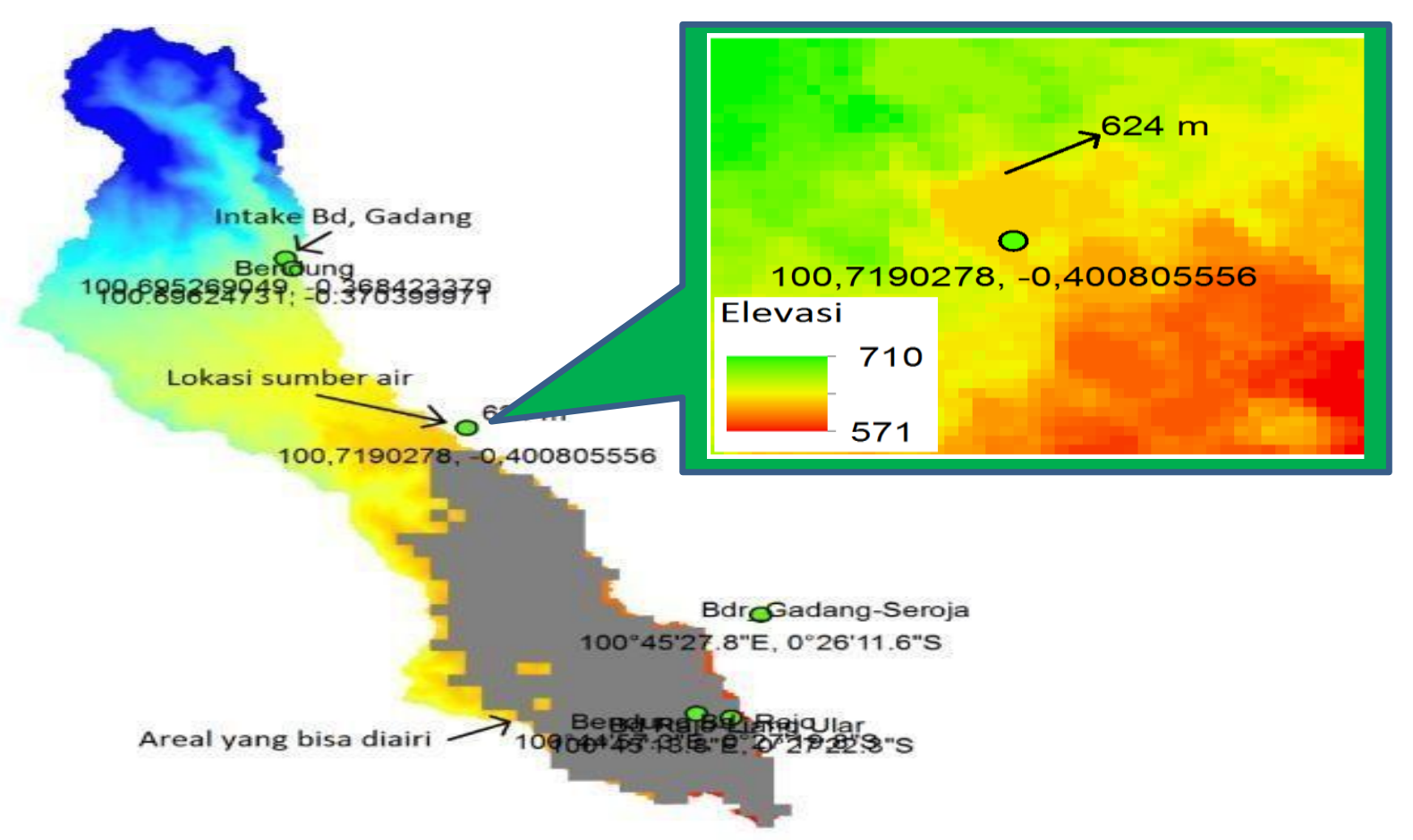

Gambar 11. Lokasi sumber air potensial dengan areal yang mungkin diairi.

Salah satu metode yang bisa memanfaatkan air tersebut adalah dengan membangun embung di hulu saluran, sehingga elevasinya bisa ditingkatkan untuk disalurkan ke sawah yang berada di bawahnya. Analisa dengan GIS menunjukkan lokasi sawah yang potensial bisa diairi oleh sumbar air ini.

\section{SIMPULAN}

Topografi dan jaringan existing elevasi pengambilan Bandar Gadang berada pada elevasi $976.25 \mathrm{~m}$. Dari Gambar 2. terlihat bahwa elevasi D.I. Tampo berada cukup tinggi dari Batang Sinamar. Pengambilan ke arah timur sebagian besar masuk ke anak-anak sungai Bt. Sinamar. Bandar Gadang kearah timur melalui Nagari Tanjung Bonai. Batang Sinamar berada pada elevasi sekitar $400 \mathrm{~m}$. Namun terlihat bahwa debit pengambilan kearah timur relatif kecil, yaitu kurang dari 20 liter/detik. Debit ini hanya mampu mengairi area di Nagari Balai 
Tangah seluas 20 hektar. Tetapi selain dari Bandar Gadang, aliran kearah timur juga disuplai oleh saluran-saluran kecil. Gabungan dari aliran Bandar Gadang dan sumber-sumber air lainnya mampu mengairi area di Nagari Tepi Selo dan Lubuk Jantan seluas 60 hektar. Tetapi untuk mengembalikan drainase dari aliran ini kembali ke Batang Tampo tidak memungkinkan, karena berada pada elevasi yang lebih rendah daripada Batang Tampo.

Salah satu metode yang bisa memanfaatkan air tersebut adalah dengan membangun embung di hulu saluran, sehingga elevasinya bisa ditingkatkan untuk disalurkan ke sawah yang berada di bawahnya.

\section{SARAN}

Perlu diperhatikan kembali kearifan lokal, yaitu melaksanakan gotong royong setiap awal musim tanam, agar sedimen yang ada disaluran dibersihkan, sehingga saluran berfungsi dengan baik.

\section{DAFTAR PUSTAKA}

1) Akbari, M., Toomanian, N., Droogers, P., Bastiaanssen, W., Gieske, A. 2007. "Monitoring irrigation performance in Esfahan, Iran, using NOAA satellite imagery". Agricultural Water Management. 88: 99-109.

2) Ali. M.H. 2010. "Fundamentals of Irrigation and On-farm Water Management". Volume 1, DOI 10.1007/978-1-4419-6335-2_2. \# Springer Science \& Business Media. LLC 2010

3) Bandara, N.J.G.J. 2003. "Water and wastewater issues in Sri Lanka". Water Sci. and Technol.

47(12), 305-312.

4) Bastiaanssen, W.G.M. 2000. "SEBALbased sensible and latent heat fluxes in the irrigated Gediz Basin, Turkey". Journal of Hydrology, 229. pp. 87-100.

5) Bastiaanssen, W.G.M. and Bos, M.G. 1999. "Irrigation performance indicators based on remotely sensed data: a review of literature". Irrigation and Drainage System. 13, pp. 291-311.
6) Bastiaanssen, W.G.M., Molden, D., Thiruvengadachari, S., Smit, A.M.F.R., Mutuwatte. I. and Jayasinghe. G. 1999. "Remote sensing and hydrologic models for performance assessment in Sirsa irrigation circle, India". Research report 27. International Water Institute. Colombo. Sri Lanka.

7) Bos, M.G., Nugteren, J. 1990.” On irrigation efficiencies". Fourth edition. ILRI.

8) BWS V. 2009. "Studi Pengembangan Kawasan Batang Tampo di Kabupaten Tanah Datar". Laporan Akhir. Balai Wilayah Sungai V Sumatera.

9) Daoliang Li, Yande Liu, Yingyi Chen. 2011. "Computer and Computing Technologies in agriculture IV" (eds): 4th IFIP TC 12.

10) Dappen, P. 2003. "Using Satellite Imagery to Estimate Irrigated Land: A Case Study in Scotts Bluff and Kearney Counties, Summer 2002”. Final Report. Center for Advanced Land Management Information Technologies (CALMIT). University of Nebraska - Lincoln.

11) El-Magd, I.A. and Tanton, T. W. 2005. "Remote sensing and GIS for estimation of irrigation crop water demand". International Journal of Remote Sensing, 26, (10), 2359-2370. (doi:10.1080/0143116042000298261).

12) Syofyan, Elvi Roza., Aguskamar, 2013." Peranan Masyarakat Dalam Pencegahan dan Penanggulangan Pencemaran Sungai". Jurnal Ilmiah POLI REKAYASA Volume 8 Nomor 2. April 2013. ISSN : 1858-3709

13) Syofyan, Elvi Roza, Amrizal Saidi, Bambang Istijono, Revalin Herdianto. "Kajian Model Hidrograf Akibat Perubahan Tataguna Lahan dengan Menggunakan Data Lapangan DAS Batang Air Dingin”. Jurnal Ilmiah POLI REKAYASA. Volume 12 Nomor 1, Oktober 2016. ISSN : 1858-3709

14) Syofyan, Elvi Roza, 2009. "Kajian Intensitas Tanam dalam Rangka Meningkatkan Produksi dan Produktivitas Lahan Daerah Irigasi Panti Rao Kabupaten Pasaman" Jurnal Ilmiah POLI 
REKAYASA. Volume 5 Nomor 1, Oktober 2009.7-17.

15) FAO 2.2014. http://www.fao.org/docrep/t0231e/t0231e 04.htm\#2.2.3 furrow irrigation. <diakses 26 April 2014>.

16) Fischer, G., Tubiello, F.N., van Velthuizen, H., Wiberg, D.A. 2007. "Climate change impacts on irrigation water requirements: effects of mitigation 1990-2080". Technological Forecasting and Social Change 74, 1083-1107.

17) Granger, R.J. 1989. "Evaporation from natural nonsaturated surfaces". Journal of Hydrology. v- 1. pp, 21-29.

18) Granger. R.J. 2000. "Satellite-derived estimates of evapotranspiration in the Gediz basin". Journal of Hydrology, 229, pp. 70-76.

19) Herdianto, R., Paik, K., Smettem, K., dan Coles., N. 2010. "Coupling vegetation index and terrain information for better representation of spatial and temporal dynamics of hydrological processes". Proceedings of 8 th International Symposium on Ecohydraulics. Seoul, September 2010. In CDROM.

20) Herdianto, R., Paik, K., Smettem, K., dan Coles., N. 2013. "Transitional responses of vegetation activities to temperature variations: Insights obtained from a forested catchment in Korea". Journal of Hydrology. Vol. 484. p.p. 86-95.
21) Knox. J.W. and Weatherhead, E.K. 1999. "The application of GIS to irrigation water resource management in England and Wales". Geographical Journal. 165, pp. 90-98.

24) Murthy, C. S.; Raju, P. V.; Jonna, S.; Hakeem, K. Abdul; Thiruvengadachari, S. 1998. "Satellite derived crop calendar for canal operation schedule in Bhadra project command area, India". International Journal of Remote Sensing. 5: 2865-2876.

25) Playan, E., and L. Mateos, 2006. "Modernization and optimization of irrigation systems to increase water productivity". Agric. Water Manage, 80(1-3): 100-116.

26) Pusat Studi Irigasi Unand. 1987. "Inventarisasi daerah irigasi Kabupaten Tanah Datar". Pusat Studi Irigasi Universitas Andalas.

27) Toomanian, N., Gieske, A.S.M. \& Akbary, M. 2004. "Irrigated area determination by NOAA- Landsat upscaling techniques, Zayandeh River Basin, Isfahan, Iran". International Journal of Remote Sensing. 25, 49454960.

28) USGS. 2014. "https://water.usgs.gov/edu/irmethods.ht ml”. <diakses 26 April 2014>. 